\title{
KEKUATAN ALAT BUKTI DALAM PERKARA PERDATA MENURUT HUKUM POSITIF INDONESIA
}

\author{
Oleh : H. ENJU JUANDA, S.H., M.H. ${ }^{*}$
}

\begin{abstract}
That in the process of settlement of disputes of civil parties to a dispute must be able to prove that the disputed object is a right and not a right of the other party. The evidence in the civil case is covering Local Examination (Article 153 HIR), Statement of Expert (Article $154 \mathrm{HIR}$ ) and evidence as mentioned in Article $164 \mathrm{HIR}$ which include written evidence, witness evidence, suspicions, Recognition and Oath.

The respective strengths that evidence vary from one to another example of the authentic, Recognition and Oath sworn perfect proofing witnesses while evidence of proof strength and foreboding force of proof under the authority of the judge.
\end{abstract}

\section{ABSTRAK}

Bahwasannya dalam proses penyelesaian sengketa keperdataan para pihak yang bersengketa harus dapat membuktikan objek yang dipersengketakan adalah merupakan haknya dan bukan merupakan hak pihak lain. Adapun alat bukti dalam proses perkara perdata adalah meliputi Pemeriksaan Setempat (Pasal $153 \mathrm{HIR}$ ), Keterangan Ahli (Pasal $154 \mathrm{HIR}$ ) dan alat bukti sebagaimana disebutkan dalam Pasal 164 HIR yang meliputi Bukti Tertulis, Bukti Saksi, Persangkaan, Pengakuan dan Sumpah.

Kekuatan masing-masing alat bukti tersebut berbeda-beda antara yang satu dengan yang lainnya misalnya Akta Otentik, Pengakuan dan Sumpah bersumpah pembuktian sempurna sedangkan alat bukti saksi kekuatan pembuktiannya dan persangkaan kekuatan pembuktiannya menjadi kewenangan hakim.

\subsection{Arti Membuktikan}

Bahwasannya dalam proses penyelesaian

keperdataan para pihak yang bersengketa mereka mengharapkan agar pengadilan memutuskan pihaknyalah yang berhak atas objek yang dipersengketakan. Sehubungan dengan hal tersebut, maka para pihak harus dapat membuktikan objek sengketa merupakan haknya dan bukan merupakan hak pihak lawan, sehingga dengan demikian pembuktian dalam proses penyelesaian sengketa keperdataan merupakan tahapan yang penting untuk dilakukan para pihak yang bersengketa.

Membuktikan adalah meyakinkan hakim tentang kebenaran dalil atau dalil-dalil yang dikemukakan dalam suatu persengketaan, (R. Subekti,1983 : 7) atau memberi dasar-dasar yang cukup kepada hakim yang memeriksa perkara yang bersangkutan guna memberi kepastian tentang kebenaran peristiwa yang diajukan (Sudikno Mertokusumo, 1998 : 109).

\footnotetext{
*) Dosen Fakultas Hukum Universitas Galuh.
} 


\subsection{Beban Pembuktian dan Resiko} Pembuktian

Apabila Penggugat menghendaki objek yang menjadi sengketa ditetapkan oleh hakim menjadi haknya, maka Penggugat harus dapat membuktikan gugatannya dan begitu pula sebaliknya apabila Tergugat menghendaki diputuskan oleh Hakim sebagai pihak yang berhak atas objek sengketa, maka Tergugat harus menyangkal atas gugatan Penggugat dan harus dapat membuktikan bahwa sangkalannya adalah benar.

Membuktikan bagi para pihak merupakan hal yang penting untuk mempertahankan sesuatu hak apabila ada pihak lainnya yang sama-sama mengakui hak tersebut, hal itu secara tegas ditentukan dalam Pasal 163 HIR, yang menyatakan sebagai berikut :

Barang siapa yang mengatakan mempunyai barang sesuatu hak atau menyebutkan sesuatu kejadian untuk meneguhkan haknya atau untuk membantah hak orang lain, maka orang itu harus membuktikan adanya hak itu atau adanya kejadian itu.

Berdasarkan ketentuan pasal tersebut di atas, tampaknya pihak utama yang harus membuktikan adalah pihak Penggugat, padahal tidak hanya Pengugat yang harus membuktikan dalilnya, melainkan Tergugat juga harus membuktikan dalilnya.
Atas dasar pembuktian yang diberikan oleh para pihak maka hakim akan menjatuhkan keputusannya kepada pihak yang memberikan pembuktian lengkap atau sempurna yaitu apabila hakim berdasarkan bukti yang telah diajukan peristiwa yang harus dibuktikan dianggap sudah pasti atau benar.

Namun meskipun bukti sudah dianggap lengkap atau sempurna masih dapat dipatahkan kesempurnaannya oleh pihak lawan yaitu apabila pihak lawan tersebut dapat membuktikan ketidakbenaran peristiwa tersebut. Sedangkan terhadap bukti yang bersifat menentukan atau memutuskan tidak dimungkinkan untuk dilumpuhkan oleh pihak lawan, misalnya terhadap pembuktian yang dilakukan dengan Sumpah Pemutus (Decisoir) tidak dapat dilumpuhkan pihak lawan (Pasal 177 $H I R)$.

\subsection{Macam-macam Alat Bukti}

Untuk meneguhkan hak seseorang atau untuk membantah hak orang lain, undang-undnag menentukan alat-alat bukti yang dapat diajukan dalam proses penyelesaian perkara perdata adalah sebagaimana yang disebutkan dalam Pasal 164 HIR yang terdiri dari Bukti tertulis, Bukti Saksi, Persangkaan, Pengakuan dan Sumpah. 
Selain alat bukti yang tercantum dalam Pasal 164 HIR juga terdapat alat bukti lain yaitu Pemeriksaan Setempat (Descente) diatur Pasal 153 HIR dan Saksi Ahli (Expertise) diatur Pasal 154 HIR. Kekuatan mengikat alat bukti tersebut berbeda antara yang satu dengan yang lainnya, karena alat bukti tersebut ada yang berkekuatan mengikat kepada hakim dan ada pula yang tidak mengikat kepada hakim melainkan diserahkan sepenuhnya kepada kewenangan hakim. Untuk mendapatkan pemahaman terhadap alat-alat bukti tersebut di atas kiranya dapat diuraikan sebagai berikut :

\section{Bukti Tertulis}

Mengenai alat bukti tertulis pengaturannya terdapat dalam Pasal 138, 165, 167 HIR, Stbl 1867 Nomor 29.

Yang dimaksud alat bukti tertulis atau surat ialah segala sesuatu yang memuat tanda-tanda bacaan yang dimaksudkan untuk mencurahkan isi hati atau buah pikiran seseorang dan dipergunakan sebagai pembuktian.

Surat sebagai alat bukti tertulis dapat dibedakan dalam akta dan surat bukan akta, selanjutnya Akta itu sendiri terdiri dari Akta Otentik dan Akta Dibawah Tangan, sehingga dengan demikian dalam hukum pembuktian dikenal tiga jenis surat, yaitu sebagai berikut :
a. Akta Otentik
b. Akta Dibawah Tangan
C. Surat Bukan Akta

Menurut A Pitlo, akta adalah suatu surat yang ditandatangani, diperbuat untuk dipakai sebagai bukti dan untuk dipergunakan oleh orang untuk keperluan siapa surat itu dibuat (Teguh Samudra, 1992 : 37).

Sudikno Mertokusumo, mengatakan bahvva akta adalah surat yang diberi tanda tangan yang memuat peristiwa yang menjadi dasar suatu hak atau perikatan, yang dibuat sejak semula dengan sengaja untuk pembuktian. Jadi untuk dapat digolongkan sebagai akta, maka surat harus ditandatangani, hal itu sebagaimana disebutkan dalam Pasal 1869 KUH Perdata.

Adapun fungsi dari tanda tangan dalam suatu akta adalah untuk memudahkan indentifikasi guna membedakan antara akta yang dibuat oleh seseorang dengan yang dibuat orang lainnya.

Sebagaimana disebutkan di atas bahwa menurut bentuknya akta terdiri dari Akta Otentik dan akta dibawah tangan. Menurut Sudikno Mertokusumo yang dimaksud dengan akta otentik adalah akta 
yang dibuat oleh pejabat yang diberi wewenang untuk itu oleh penguasa, menurut ketentuan-ketentuan yang telah ditetapkan, baik dengan maupun tanpa bantuan dari yang berkepentingan yang mencatat apa yang dimintakan untuk dimuat didalamnya oleh yang berkepentingan.

Sedangkan dalam HIR tentang akta otentik terdapat dalam Pasal 165 menyatakan : akta otentik yaitu suatu surat yang diperbuat oleh atau dihadapan pegawai umum yang berkuasa akan membuatnya, mewujudkan bukti yang cukup bagi kedua belah pihak dan ahli warisnya serta sekalian orang yang mendapat hak dari padanya yaitu tentang segala hal vang tersebut dalam surat itu dan juga tentang yang tercantum dalam surat itu sebagai pemberitahuan saja tetapi yang tersebut kemudian Itu hanya sekedar yang diberitahukan itu langsung berhubungan dengan pokok dalam akta itu.

Atas dasar dari pengertian di atas, maka dapat disebutkan unsur pokok akta otentik yaitu akta yang dibuat oleh dan atau dihadapan pejabat umum yang dimaksud pejabat umum misalnya Notaris, Hakim, Panitera, Juru Sita, Pegawai
Pencatat Sipil, sehingga surat yang dikeluarkan oleh pejabat yang bersangkutan seperti Akta Notaris, Vonis, Berita Acara Sidang, Berita Acara Penyitaan, Akta Perkawinan, Akta Kelahiran adalah merupakan Akta Otentik.

Akta otentik itu sendiri menurut Pasal 165 HIR terdiri dari dua, yaitu :

1. Akta yang dibuat oleh pejabat. Dalam hal ini merupakan akta yang dibuat oleh pejabat yang berwenang untuk itu dengan ma na pejabat tersebut menerangkan apa yang dilihat serta apa yang diketahuinya. Jadi inisiatifnya tidak berasal dari orang yang namanya diterangkan didalam akta itu. Contohnya berita acara yang dibuat oleh polisi, berita acara persidangan yang dibuat oleh panitera pengganti.

2. Akta yang dibuat dihadapan pejabat yang diberi wewenang untuk itu adalah akta yang dibuat oleh pejabat atas permintaan pihak-pihak yang berkepentingan. Contohnya akta notaris tentang jual beli atau sewa menyewa.

Untuk jelasnya perbedaan antara akta yang dibuat oleh dan akta yang dibuat dihadapan pejabat yang berwenang adalah sebagai 
berikut (Teguh Samudra, 1992:4243) :

Pada akta otentik yang dibuat oleh pejabat umum :

- Inisiatif datang dari para pihak.

- Pihaknya mengetahui benar tentang hal-hal yang dikemukakan dalam akta (isi akta).

Pada akta otentik yang dibuat dihadapan pegawai umum

- Pegavvai umum tidak pernah memulai inisiatifnya.

- Pegawai umum tidak tahu benar kebenaran dari hal-hal yang dikemukakan oleh keclua belah pihak yang hadir dihadapannya (isi dari akta).

Akta otentik merupakan bukti yang cukup, hal itu berarti bahwa dengan dihaturkannya akta kelahiran anak misalnya, sudah terbukti secara sempurna tentang kelahiran anak tersebut dan perihal itu tidak perlu penambahan pembuktian lagi. Atau dengan kata lain akta otentik berkekuatan pembuktian sempurna yang berarti bahwa isi akta tersebut oleh hakim dianggap benar kecuali apabila diajukan bukti lawan yang kuat. Jadi hakim harus mempercayai apa yang tertulis dalam akta itu dan harus dianggap benar selama ketidakbenarannya tidak dapat dibuktikan.

Hal itu disebabkan karena akta otentik itu dibuat oleh pejabat yang terikat pada syarat-syarat dan ketentuan-ketentuan dalam undangundang, sehingga hal itu cukup merupakan jaminan dapat dipercayainya pejabat tersebut, maka isi dari akta otentik itu cukup dibuktikan oleh akta itu. Jadi dianggaplah bahwa akta otentik itu dibuat sesuai dengan kenyataan seperti yang dilihat oleh pejabat itu sampai dibuktikan sebaliknya.

Mengenai

kekuatan pembuktian akta otentik, dapat diklasifikasikan sebagai berikut (Retnowulan Sutantio dan Iskandar Oeripkartawinata, 1997 : 67-68) :

1. Kekuatan pembuktian formil. Membuktikan antara para pihak bahwa mereka sudah menerangkan apa yang ditulis dalam akta tersebut.

2. Kekuatan pembuktian materiil. Membuktikan antara para pihak bahwa benar-benar peristiwa yang tersebut dalam akta itu telah terjadi.

3. Kekuatan mengikat. Membuktikan antara para pihak dan pihak ketiga bahwa pada tanggal yang tersebut dalam akta 
yang bersangkutan telah menghadap kepada pegawai umum tadi dan menerangkan apa yang ditulis dalam akta tersebut, oleh karena menyangkut pihak ketiga, maka disebutkan bahwa akta otentik mempunyai kekuatan pembuktian keluar (orang luar).

Akta dibawah tangan adalah akta yang sengaja dibuat untuk pembuktian oleh para pihak tanpa bantuan dari seorang pejabat. Jadi semata-mata dibuat antara para pihak yang berkepentingan.

Akta dibawah tangan mempunyai kekuatan hukum sempurna apabila tanda tangan yang tercantum dalam akta dibawah tangan diakui oleh para pihak yang membuatnya. Hal itu sebagaimana ditentukan dalam Pasal 2 Stbl 1867 Nomor 29 yang menentukan apabila tanda tangan yang tercantum dalam akta dibawah tangan diakuti oleh yang membuatnya, maka akta dibawah tangan itu berkekuatan hukum sempurna seperti akta otentik.

Cara mengakui tanda tangan tersebut adalah pengakuan yang berbunyi : tanda tangan itu betul tanda tangan saya dan isi tulisan itu adalah benar (Wirjono Prodjodikoro, $1982: 110)$.
Apabila tanda tangan yang terdapat dalam akta dibawah tangan disangkal oleh pihak yang menandatangani akta tersebut, maka pihak yang mengajukan akta dibawah tangan itu harus berusaha membuktikan kebenaran tanda tangan itu dengan kata lain apabila tanda tangan disangkal, maka hakim harus memeriksa kebenaran tanda tangan tersebut.

Dengan berkekuatan bukti sempurna maka terhadap akta dibawah tangan itu mempunyai kekuatan seperti akta otentik (sebagaimana dikemukakan Retnowulan Sutantio di atas) kecuali tidak mempunyai kekuatan mengikat kepada pihak ketiga.

\section{Bukti Saksi}

Saksi adalah orang yang memberikan keterangan/kesaksian di depan pengadilan mengenai apa yang mereka ketahui, lihat sendiri, dengar sendiri atau alami sendiri, yang dengan kesaksian itu akan menjadi jelas suatu perkara (Darwan Prinst, 1996 : 181).

Kesaksian adalah kepastian yang diberikan kepada hakim dipersidangan tentang peristiwa yang disengketakan dengan jalan pemberitahuan secara lisan dan 
pribadi oleh orang yang bukan salah satu pihak dalam perkara yang dipanggil di persidangan (Sudikno Mertokusumo, 1998 : 135).

Kesaksian ini adalah wajar dan penting. Wajar karena dalam pemeriksaan di pengadilan sudah selayaknya untuk didengar keterangan pihak ketiga yang tidak termasuk dalam pihak yang bersengketa. Penting karena seringkali di jumpai dalam praktek tidak ada bukti tertulis atau alat bukti yang lainnya. Hal ini disebabkan karena terutama dalam suasana Hukum Adat/ Masyarakat Adat dalam melakukan perbuatan hukum dilakukan secara lisan.

Keterangan seorang saksi harus disampaikan secara lisan dan pribadi artinya tidak boleh diwakilkan kepada orang lain dan harus dikemukakan secara lisan disidang pengadilan. Sehingga kesaksian yang didengar dari orang lain yang disebut testimonium de auditu adalah umumnya tidak diperkenankan, karena keterangan itu tidak berhubungan dengan peristiwa yang dialami sendiri. Dengan demikian maka saksi de audtiu bukan merupakan alat bukti dan tidak perlu dipertimbangkan hakim (Sudikno Mertokusumo, 1998:138).

Akan tetapi keterangan dari pendengaran dapat dipergunakan untuk menyusun persangkaan atau untuk memperlengkapi keterangan saksi-saksi yang bisa dipercaya. Berdasarkan hal itu. pendapat bahwa saksi de auditu sama sekali tidak berarti adalah keliru. Karena kesaksian de auditu dapat dipergunakan sebagai sumber persangkaan (Retnowulan Sutantio dan Iskandar Oeripkartawinata, 1997 : 74).

Untuk membuktikan sesuatu dengan saksi maka sekurangkurangnya harus didukung oleh dua orang saksi, karena dalam Hukum Acara Perdata terdapat asas Unus Testis Nulus Testis artinya satu saksi bukan saksi (Pasal 169 HIR).

Pasal 171 HIR menentukan bahwa agar keterangan saksi dapat dipercaya, maka saksi juga harus dapat menjelaskan sebab musabab sehingga saksi mengetahui peristiwa yang diterangkannya.

Kesaksian tidak mengikat kepada hakim dan untuk dapat tidaknya seorang saksi dipercaya menurut Pasal 172 HIR menentukan bahwa dalam mempertimbangkan nilai kesaksian harus diperhatikan 
kesesuaian antara saksi yang satu dengan saksi yang lainnya, kesesuaian kesaksian dengan apa yang diketahui dari segi lain tentang perkara yang disengketakan, pertimbangan yang mungkin ada pada saksi untuk memberikan kesaksian, cara hidup, adat istiadat serta harkat dan martabat saksi dalam masyarakat dan segulu sesuatu yang sekiranya mempengaruhi tentang dapat tidaknya dipercayai seorang saksi.

Pada prinsipnva setiap orang boleh jadi saksi kecuali bagi orangorang tertentu yang tidak dapat didengar sebagai saksi, yaitu sebagai berikut (Sudikno

Mertokusumo, 1998 : 141-142) :

1. Ada segolongan orang yang dianggap tidak mampu untuk bertindak sebagai saksi. Mereka ini dibedakan antara mereka yang dianggap tidak mampu secara mutlak dan mereka yang dianggap tidak mampu secara nisbi.

a. Mereka yang tidak mampu secara mutlak (absolut). Hakim dilarang untuk mendengar mereka ini sebagai saksi. Mereka adalah :

1) Keluarga sedarah dan keluarga semenda menurut keturunan yang lurus dari salah satu pihak (Pasal 145 ayat (1) sub 1 HIR, 172 ayat (1) sub I RBg 1910 alinea I BW). Adapun alasan pembentuk undang-undang

memberikan batasan ini adalah sebagai berikut :

- Bahwa mereka ini pada umumnya dianggap tidak cukup obyektif apabila didengar sebagai saksi.

- Untuk menjaga hubungan

kekeluargaan yang baik, yang mungkin akan retak apabila mereka ini memberi kesaksian.

Untuk mencegah timbulnya tekanan bathin setelah memberi keterangan.

Akan tetapi menurut Pasal 145 ayat (2) HIR (Pasal 172 ayat (2) $\mathrm{RBg}, 1910$ alinea 2 BW) mereka ini tidak boleh ditolak sebagai saksi dalam perkara yang menyangkut kedudukan keperdataan dari para pihak atau dalam perkara yang menyangkut perjanjian kerja. Pasal 1910 alinea 2 sub 2 dan 3 BW menambahkan dengan hal-hal yang berhubungan dengan pemberian nafkah dan penyelidikan tentang hal-hal yang menyebabkan

pencabutan kekuasaan orang tua dan perwalian. Dalam hubungan ini mereka ini tidak berhak mengundurkan diri dari memberi kesaksian.

2) Suami atau isteri dari salah satu pihak, 
meskipun sudah bercerai (Pasal 145 ayat (1) sub 2 HIR, 172 ayat (1) sub 3 RBg, 1910 alinea 1 BW).

b. Mereka yang tidak mampu sccara nisbi (relatif). Mereka ini boleh didengar, akan tetapi tidak sebagai saksi. Termasuk mereka yang boleh didengar, akan tetapi tidak sebagai saksi, yaitu :

1) Anak-anak yang belum mencapai umur 15 tahun (Pasai 145 ayat (1) sub 3 jo ayat (4) HIR, Pasal 172 ayat (1) sub 4 jo $173 \mathrm{RBg}$, 1912 BW).

2) Orang gila meskipun kadang-kadang

ingatannya terang atau sehat (Pasal 145 ayat (1) sub $4 \mathrm{HIR}, 172$ ayat (1) sub 5 RBg, 1912 BW. Mereka yang diletakkan di bawah pengampuan karena boros dianggap cakap bertindak sebagai saksi.

Keterangan mereka ini hanyalah boleh dianggap sebagai penjelasan belaka. Untuk memberi keterangan tersebut mereka tidak perlu disumpah (Pasal 145 ayat (4) HIR, $173 \mathrm{RBg}$.

Ada segolongan orang yang atas permintaan mereka sendiri dibebaskan dari kewajibannya untuk memberi kesaksian. Mereka yang boleh mengundurkan diri ini adalah (Pasal 146 HIR, 174 RBg, 1909 alinea 2 BW : hak ingkar, verschoningsrecht). a. Saudara laki-laki dan perempuan serta ipar laki-laki dan perempuan dari salah satu pihak.

b. Keluarga sedarah menurut keturunan yang lurus dan saudara laki-laki dan perempuan daripada suami atau isteri salah satu pihak.

c. Semua orang yang karena martabat, jabatan atau hubungan kerja yang sah diwajibkan mempunyai rahasia, akan tetapi semata-mata hanya tentang hal yang diberitahukan kepadanya karena martabat, jabatan atau hubungan kerja yang sah saja. Hal ini mengingat kenyataan bahwa didalam masyarakat sering kita terpaksa mempercayakan hal-hal yang menyangkut pribadi kepada orang tertentu. Hak mengundurkan diri ini hanya berlaku terhadap peristiwaperistiwa yang dipercayakan kepada orang yang harus merahasiakannya berhubung dengan martabat, jabatan atau hubungan yang sah. Hak mengundurkan diri ini diberikan kepada dokter, advocaat, notaris dan polisi.

Bagi seorang saksi yang dipanggil kepersidangan di 
pengadilan melekat tiga bahwa anak tersebut adalah kewajiban yaitu sebagai berikut :

1. Kewajiban untuk menghadap. anak angkat dari $A$ dan $B$.

2. Kewajiban untuk bersumpah.

3. Kewajiban untuk memberi keterangan.

\section{Persangkaan}

Dalam HIR yang menyangkut persangkaan terdapat dalam Pasal 173 dan dalam pasal tersebut tidak dijelaskan apa yang dimaksud persangkaan karena hanya ditentukan bahwa persangkaan itu dapat digunakan sebagai alat bukti apabila persangkaan itu penting, seksama, tertentu dan ada persesuaian satu sama lainnya.

Menurut Retnowulan Sutantio dan Iskandar Oeripkartawinata yang dimaksud persangkaan adalah kesimpulan yang ditarik dari suatu peristiwa yang telah dianggap terbukti atau peristiwa yang dikenal, kearah suatu peristiwa yang belum terbukti.

Misalnya :

Apabila seorang anak telah dipelihara, dikhitan serta dikawinkan oleh keluarga $\mathrm{A}$ dan meskipun ia sesungguhnya adalah keluarga lain tetapi juga anak tersebut memanggil mak dan Bapak kepada $A$ dan $B$, hal itu akan memberikan persangkaan kepada hakim

Untuk dapat dijadikan alat bukti, persangkaan tidak dapat dengan satu persangkaan saja. Tetapi harus terdiri dari beberapa persangkaan, memang hal itu tidak diatur secara tegas dalam HIR akan tetapi hal itu menurut Subekti bahwa pasal-pasal yang mengatur bahwa satu saksi bukan saksi harus juga dianggap berlaku bagi persangkaan sehinga dalam hal ini hakim dilarang mengabulkan gugatan hanya dengan berdasarkan pada satu persangkaan saja. Hal itu dapal disimpulkan dari kalimat terakhir Pasal 173 HIR yang berbunyi : ... dan bersetujuan satu dengan yang lain....

Dari kalimat itu berarti harus terdiri dari beberapa persangkaan yang satu dengan lainnya saling berhubungan.

Menurut IImu Pengetahuan persangkaan dibagi menjadi dua, yaitu (Sudikno Mertokusumo, 1995 : 146-147) :

1. Persangkaan berdasarkan kenyataan (feitelijke atau rechtlijke vermoedens, praesumptiones facti). Pada persangkaan ini hakimlah yang memutuskan berdasarkan kenyataannya apakah mungkin dan sampai sejauhmana kemungkinannya untuk membuktikan suatu peristiwa 
tertentu dengan membuktikan peristiwa lain. Misalnya : peristiwa A diajukan, maka hakim memutuskan apakah peristiwa B ada hubungannya yang cukup erat dengan peristiwa $A$ untuk menganggap peristiwa $A$ terbukti dengan terbuktinya peristiwa $B$.

2. Persangkaan berdasarkan hukum undang-undang (wettelijke atau rechtsvermoedens, praesumptiones juris). Pada persangkaan ini maka undangundanglah yang menerapkan hubungan antara peristiwa yang diajukan dan harus dibuktikan dengan peristiwa yang tidak diajukan. Sangkaan berdasarkan hukum dibagi dua, yaitu :

- preasumptiones juris tantum yaitu persangkaan berdasarkan hukum yang memungkinkan pembuktian lawan.

- Preasumptions juris et de jure, yaitu persangkaan berdasarkan hukum yang tidak memungkinkan pembuktian lawan.

Apabila kita hubungkan dengan persangkaan tersebut di atas, maka menurut Pasal 173 HIR hanya menyebut sebagai persangkaan menurut kenyataan.

Lain lagi apabila kita menengok ketentuaan Pasal 1915 Kitab Undang-undang Hukum Perdata yang menentukan bahwa persangkaan adalah kesimpulankesimpulan yang oleh undangundang atau hakim ditarik dari suatu peristiwa yang terang nyata kearah peristiwa lain yang belum terang kenyataannya.

Jadi menurut Pasal 1915 Kitab Undang-undang Hukum Perdata dikenal adanya dua persangkaan yaitu persangkaan yang didasarkan atas undangundang (praesumptiones juris) dan persangkaan berdasarkan kenyataan (praesumtiones factie).

Kekuatan

pembuktian

persangkaan adalah sebagaimana dikemukakan oleh Abdulkadir Muhammad yang menyatakan bahwa pembuktian dengan persangkaan berdasarkan kenyataan tidak bersifat memaksa, terserah pada kebijaksanaan hakim untuk menggunakan atau tidak, sedangkan terhadap persangkaan menurut hukum (undang-undang) ia mempunyai kekuatan bukti yang bersifat memaksa, karena telah ditentukan secara tegas dalam undang-undang (Pasal 1916 Kitab Undang-undang Hukum Perdata) jadi hakim terikat kepadanya,

Persangkaan yang ditentukan Pasal 1916 Kitab Undang-undang Hukum Perdata adalah sebagai berikut :

1. Perbuatan-perbuatan yang oleh undang-undang dinyatakan batal, 
karena dari sifat dan keadaannya saja dapat diduga dilakukan untuk menghindari ketentuanketentuan undang-undang.

2. Peristiwa-peristiwa yang menurut undang-undang dapat dijadikan kesimpulan guna menerapkan hak pemilikan atau pembebasan dari utang.

3. Kekuatan yang diberikan oleh undang-undang kepada putusan hakim.

4. Kekuatan yang diberikan oleh undang-undang kepada pengakuan atau sumpah oleh salah satu pihak.

\section{Pengakuan}

Pengakuan dalam HIR pengaturannya terdapat dalam Pasal-pasal 174, 175 dan Pasal 176. Apabila kita melihat ketentuan Pasal 164 HIR, maka jelas pengakuan menurut undang-undang merupakan salah satu alat bukti dalam proses penyelesaian perkara perdata.

Akan tetapi meskipun demikian para ahli hukum banyak mengatakan bahwa pengakuan bukan merupakan alat bukti, dengan alasan bahwa kurang tepat menamakan pengakuan sebagai alat bukti, karena justru apabila dalil salah satu pihak telah diakui oleh pihak lain, maka dalil tersebut sebenarnya tidak usah dibuktikan lagi (Retnowulan Sutantio dan Iskandar Oeripkartawinata, 1997 : 80).

Atau seperti pula yang dikemukakan A Pitlo sebagai berikut bahwa dengan mengaku, maka para pihak telah memungkinkan hakim memberikan pendapatnya tentang obyek dari pengakuan, jadi hakim tidak akan menyelidiki kebenaran dari suatu pengakuan (Teguh Samudra, $1992: 83$ ).

Ahli lain yang menyatakan pengakuan bukan alat bukti adalah yang menyebutkan bahwa apabila dalil-dalil yang dikemukakan oleh pihak diakui oleh pihak lawan, maka pihak yang mengemukakan dalil-dalil itu tidak usah membuktikannya (R. Subekti, 1997 : 49).

Undang-undang tidak menjelaskan apa yang dimaksud dengan pengakuan, maka kita harus mencarinya dalam doktrin seperti yang dikemukakan A. Pitlo sebagai berikut pengakuan adalah keterangan sepihak dari salah satu pihak dalam suatu perkara dimana ia mengakui apa yang dikemukakan oleh pihak lawan atau sebagian dari apa yang dikemukakan oleh pihak lawan (Teguh Samudra 1992 : 83). 
Hukum Acara Perdata mengenal dua macam Pengakuan yaitu Pengakuan yang dilakukan di depan sidang dan Pengakuan yang dilakukan diluar sidang.

Pengakuan yang dilakukan di depan sidang merupakan keterangan sepihak baik tertulis maupun lisan yang tegas dan dinyatakan oleh salah satu pihak dalam perkara dipersidangan yang membenarkan baik seluruhnya atau sebagian dari suatu peristivva, hak atau hubungan hukum yang diajukan oleh lawannya yang mengakibatkan pemeriksaan lebih lanjut oleh hakim tidak diperlukan lagi (Sudikno Mertokusumo, 1998 : 149).

Pengakuan ini dapat dilakukan baik langsung oleh yang bersangkutan maupun oleh orang lain yang diberi kuasa khusus untuk itu baik secara lisan maupun tulisan dalam jawaban. Dalam mengakui sesuatu hal di depan hakim haruslah berhati-hati karena pengakuan yang dilakukan di depan sidang tidak dapat ditarik kembali kecuali apabila ia dapat membuktikan bahwa pengakuannya adalah akibat dari kekhilafan tentang fakta-takta (Pasal 1926 Kitab Undang-undang Hukum Perdata).
Menurut Pasal 174 HIR menentukan bahwa pengakuan yang dilakukan di depan sidang mempunyai kekuatan pembuktian sempurna dan mengikat bahkan menurut Pasal 1916 ayat (2) Nomor 4 Kitab Undang-undang Hukum Perdata bersifat menentukan dan tidak memungkinkan bukti lawan.

Hal itu berarti bahwa hakim harus menganggap dalil-dalil yang telah diakui itu adalah benar meskipun pada kenyataannya hal tersebut tidak benar, akan tetapi dengan adanya pengakuan tersebut gugatan yang didasarkan atas dalildalil itu harus dikabulkan. Sedangkan pengakuan yang dilakukan diluar sidang adalah keterangan yang diberikan oleh salah satu pihak dalam suatu perkara perdata diluar sidang untuk membenarkan pernyataanpernyataan dalil-dalil yang dibenarkan oleh lawannya dapat dilakukan dengan lisan dan tulisan.

Menurut Pasal 175 HIR pengakuan di luar sidang kekuatan pembuktiannya diserahkan kepada kebijaksanaan hakim atau dengan kata lain pengakuan diluar sidang merupakan bukti bebas bagi hakim, hal itu berarti bahwa hakim leluasa untuk memberi kekuatan pembuktian 
atau pula hanya menganggap bukti permulaan.

Dengan demikian pengakuan di luar sidang baik lisan maupun tulisan merupakan bukti bebas dengan perbedaan sebagai berikut bahwa terhadap pengakuan diluar sidang secara tertulis tidak usah dibuktikan lagi tentang adanya pengakuan tersebut, sedangkan bagi pengakuan diluar sidang yang dilakukan secara lisan, apabila dikehendaki agar dianggap terbukti adanya pengakuan semacam itu harus dibuktikan lebih lanjut dengan saksi atau alat bukti lainnya. Pengakuan diluar sidang dapat ditarik kembali (Sudikno Mertokusumo, 1998 : 154).

Mengenai pengakuan dalam ilmu pengetahuan diklasifikasikan menjadi tiga, yaitu (Sudikno Menokusumo, 1998:151-152) :

1. Pengakuan murni (aveu pur et simple) yaitu pengakuan yang sifatnya sederhana dan sesuai sepenuhnya dengan tuntutan pihak lawan. Misalnya penggugat menyatakan bahwa tergugat telah membeli rumah dari penggugat dengan harga $\mathrm{Rp}$ 5.000.000,00, tergugat memberi jawaban bahwa ia membeli rumah penggugat dengan harga Rp 5.000.000,00.
2. Pengakuan dengan kualifikasi (gequalificeerde bekentenis, aveu qualifie) adalah pengakuan yang disertai dengan sangkalan terhadap sebagian dari tuntutan Misalnya penggugat menyatakan bahwa tergugat telah membeli rumah dari penggugat seharga Rp. 5.000.000,00, tergugat mengaku telah membeli rumah dan penggugat tetapi bukan $\mathrm{Rp}$ $5.000 .000,00$ melainkan $\mathrm{Rp}$ 3.000.000,00.

Jadi pengakuan dengan kualitlkasi adalah jawaban tergugat yang sebagian pengakuan dan sebagian sangkalan.

3. Pengakuan dengan klausula (geclausuleerde bekentenis, aveu complexe). Yaitu pengakuan yang disertai dengan keterangan tambahan yang bersifat membebaskan. Misalnya penggugat menyatakan bahwa tergugat telah membeli rumah penggugat seharga $R p$. 5.000.000,00, tergugat mengakuai telah mengadakan perjanjian jual beli rumah milik penggugat seharga $\mathrm{Rp}$ 5.000.000,00, tetapi ditambahkannya bahwa harga rumah telah dibayar lunas.

Keterangan tambahan atau klausula umumnya seperti pembayaran pembebasan, kompensasi. 
Jadi pengakuan dengan klausula merupakan pengakuan tentang hal pokok yang diajukan oleh penggugat, tetapi disertai dengan tambahan penjelasan yang menjadi dasar penolakan gugatan.

Ketiga jenis pengakuan tersebut di atas dapat pula diklasiflkasikan menjadi pengakuan bulat/murni dan pengakuan berembel-embel yang meliputi pengakuan dengan klausula dan pengakuan dengan kualifikasi (Retnowulan dan Iskandar Oeripkartawinata 1997 : 82-83).

Dalam hubungannya dengan pengakuan berklausula dan berkualifikasi haruslah diterima hakim secara bulat dan tidak boleh dipisah-pisahkan dari keterangan tambahannya. Hal itu sebagaimana ditetapkan Pasal 176 HIR yang mengandung ajaran pengakuan tidak boleh dipisah-pisahkan atau dikenal dengan asas onsplitbare aveu. Untuk mendapatkan pemahaman mengenai penerapan asas onsplitbare aveu ini ada baiknya apabila kita melihat contoh yang disebutkan Teguh Samudra sebagai berikut :
A meminjam uang kepada $B$, tanpa suatu bukti apapun, jadi hanya didasarkan pada saling percaya belaka, akan tetapi A telah mengembalikan pinjaman tersebut kepada B. pembayarannya pun tidak disertai bukti pembayaran. Kemudian B menuntut lagi kepada $A$ agar membayar utangnya. Disini A mengaku berhutang kepada $B$ akan tetapi ia telah membayar lunas. Jika terjadi hal demikian dan tidak ada aturan Pasal 176 HIR (Pasal 1924 KUH Perdata), maka hakim dapat berbuat menerima pengakuan $A$ tersebut dan $A$ harus membuktikan bahwa ia sudah membayar, sedangkan hal ini sulit dibuktikan A karena tanpa adanya bukti pembayaran dan berarti akan memberatkan A, sebaliknya juga mengingat bahwa perjanjian utang piutang antara A dan B itu tidak ada buktinya, maka daripada $A$ dikalahkan dengan memisahkan pengakuannva tadi akan lebih baik jika ia menolak seluruh tuntutan $B$, karena dalam hal inipun apabila B diharuskan membuktikan adanya persetujuan pinjam meminjam uang yang telah diakui A, B-pun akan mendapatkan kesulitan besar mengingat perjanjian itu tidak ada alat buktinya, maka disini akan terlihat adanya kesulitan yang sama antara para pihak yaitu 
pihak B sulit membuktikan adanya persetujuan pinjam meminjam sedangkan $A$ sulit membuktikan telah membayar utangnya disebabkan oleh keduanya tidak ada satupun alat pembuktian, maka sudah selayaknya jika hakim dalam hal ini mengikuti ketentuan Pasal 176 HIR.

\section{Sumpah}

Alat bukti sumpah pengaturannya terdapat dalam Pasal 155-158, 177 HIR.

Alat bukti sumpah dapat digunakan sebagai upaya terakhir dalam membuktikan kebenaran dari suatu proses perkara perdata, karena sepanjang alat bukti lainnya masih dapat diupayakan maka sumpah lebih baik ditangguhkan penggunaannya.

Sumpah pada umumnya
adalah suatu pernyataan yang
khidmat yang diberikan atau
diucapkan pada waktu memberi janji
atau keterangan dengan mengingat
akan sifat Maha Kuasa dari Tuhan
Yang Maha Esa dan percaya bahwa
siapa yang memberi keterangan atau
janji yang tidak benar akan dihukum
oleh-Nya (Sudikno Mertokumo,
1998:155).

Jadi pada hakekatnya sumpah merupakan tindakan yang bersifat religius yang digunakan dalam peradilan.

Selanjutnva dari defiisi sumpah tersebut di atas Sudikno Mertokusumo, membagi sumpah menjadi dua, yaitu :

a. Sumpah Promissoir yaitu sumpah untuk berjanji melakukan atau tidak melakukan sesuatu. Termasuk sumpah promissioir adalah sumpah saksi dan sumpah (saksi) ahli, karena sebelum memberikan kesaksian atau pendapatnva harus diucapkan pernyataan atau janji akan memberi keterangan yang benar dan tidak lain daripada yang sebenarnya.

b. Sumpah Assertoir atau Confirmatoir yaitu sumpah untuk member! keterangan guna meneguhkan bahvva sesuatu itu benar demikian atau tidak. Sumpah confimatoir ini merupakan sumpah sebagai alat bukti karena fungsinya adalah untuk meneguhkan (confirm) suatu peristiwa.

Dalam Hukum Acara Perdala dikenal tiga macam sumpah sebagai alat bukti, yaitu (Sudikno Mertokumo, $1998: 155-100)$ : 
a. Sumpah Pelengkap (Suppletoir) diatur dalam Pasal 155 HIR 182 RBg yaitu sumpah yang diperintahkan oleh hakim karena jabatannya untuk melengkapi pembuktian peristiwa yang menjadi sengketa sebagai dasar putusannya. Sumpah pelengkap dibebankan oleh hakim kepada salah satu pihak untuk melengkapi pembuktian peristiwa yang menjadi sengketa sebagai dasar putusannya, tetapi dalam hal ini hakim tidak bersifat wajib untuk membebankannya tetapi dalam hal ini hanya mempunyai kewenangan. Untuk dapat diperintahkan sumpah suppletoir kepada salah satu pihak harus ada pembuktian permulaan terlebih dahulu, akan tetapi alat bukti itu belum mencukupi sedangkan alat bukti lainnya tidak mungkin untuk didapatkan sehingga apabila ditambah dengan sumpah suppletoir hakim dapat menjatuhkan putusannya. Misalnya apabila dalam suatu perkara perdata hanya ada satu saksi saja, maka untuk menjadi bukti sumpurna hakim berwenang untuk memerintahkan sumpah untuk melengkapi satu saksi tersebut.
Karena sumpah suppletoir mempunyai fungsi menyelesaikan suatu perkara, maka mempunyai kekuatan bukti sempurna yang masih memungkinkan pembuktian pihak lawan. Pihak yang dibebani sumpah penambah/pelengkap tidak dapat mengembalikan sumpah itu untuk dibebankan kepada pihak lawannya, tetapi hanya dapat menerima atau menolak.

b. Sumpah Penaksiran (Aestimatoir, Schattingseed), diatur dalam Pasal 155 H1R (Pasal 182 RBg, Pasal 1940 KUH Perdata), yaitu sumpah yang diperintahkan oleh hakim karena jabatannya kepada penggugat untuk menentukan jumlah uang ganti kerugian. Syarat pembebanan sumpah penaksiran adalah kesalahan pihak tergugat telah terbukti, namun jumlah kerugian sulit ditentukan.

Untuk mengatasi persoalan tersebut hakim karena jabatannya dapat mengabulkan sejumlah uang yang harus dibayar oleh pihak tergugat, sedangkan besarnya kerugian akan ditetapkan atau ditaksir oleh pengadilan, karena hal tersebut maka sumpah ini disebut sumpah 
penaksir. Misalnya : dalam hal telah terjadi kebakaran yang disebabkan oleh anak tergugat dan barang-barang penggugat musnah sehingga sukar untuk menentukan kerugian yang diderita oleh penggugat.

Jadi sumpah penaksir dilakukan untuk menentukan besarnya ganti rugi yang diminta penggugat dan tentang adanya kerugian telah terbukti. Kekuatan pembuktian sumpah penaksir berkekuatan pembuktian sempurna yang masih memungkinkan dilumpuhkan pihak lawan.

c. Sumpah Pemutus (decisoir) diatur dalam Pasal 156. 157, 177 $H 1 R$, yaitu sumpah yang oleh pihak yang satu melalui perantaraan hakim diperintahkan kepada pihak lainnya untuk menggantungkan pemutusan perkara tersebut. Pelaksanaan sumpah tersebut harus sunguhsungguh dapat mengakhiri perkara, sehingga sumpah ini bersifat menentukan (litis decisoir). Sumpah deccisoir merupakan upaya terakhir atau dengan kata lain merupakan senjata pamungkas untuk menyelesaikan suatu perkara. Inisiatif untuk membebani sumpah pemutus datangnya dari salah satu pihak dan ia pula yang menyusun rumusan sumpahnya. Apabila salah satu pihak memerintahkan sumpah pemutus kepada pihak lawannya berarti pihak tersebut dianggap sebagai pihak yang melepaskan hak yang ada padanva, seolah-olah orang itu menyatakan kepada pihak lawannya sebagai berikut :

"Baiklah kalau kamu berani bersumpah saya rela untuk dikalahkan" perintah untuk melakukan sumpah pemutus dapat dikembalikan artinya pihak yang menerima perintah dapat menuntut supaya si pemberi perintah itu dikembalikan dan tidak berani bersumpah, maka ia akan dikalahkan. Dalam hal yang demikian, maka terjadilah bahwa senjata itu makan tuannva sendiri (R.Subekti, 1969 : 19).

Maka sccara tegas dapat dikatakan bahwa siapa yang melaksanakan sumpah atas perintah lawannya, maka pada dialah letak putusan kemenangan dan berarti perkara itu dengan sendirinya selesai sebaliknya apabila dia menolak melakukan sumpah, maka dialah yang 
dikalahkan dalam perkara tersebut.

Hal tersebut karena akibat mengucapkan sumpah decisoir adalah bahwa kebenaran peristiwa yang dimintakan sumpah menjadi pasti dan pihak lawan tidak boleh membuktikan bahwa sumpah itu palsu, tanpa mengurangi wewenang Jaksa Penuntut Umum untuk menuntut berdasarkan sumpah palsu yang diatur dalam Pasal 242 Kitab Undang-undang Hukum Pidana. Oleh karena itu sumpah pemutus merupakan bukti sempurna bahkan bersifat menentukan. Sumpah decisoir harus dilakukan dipersidangan dan harus diiakukan dihadapan pihak lawannya. Tetapi berdasarkan Pasal 381 HIR pelaksanaan sumpah decisoir dapat berupa sumpah pocong, sumpah mimbar (sumpah gereja), sumpah kelenteng. Dalam hal sumpah pocong yang dilakukan di mesjid, pihak yang akan melaksanakan sumpah dibungkus kain kafan seolah-olah yang bcrsangkutan telah meninggal dunia.

\subsection{Penutup}

Bahwasannya berdasarkan uraian tersebut di atas kiranya para pihak yang bersengketa dalam perkara keperdataan membuktikan merupakan tahapan proses yang sangat penting untuk menentukan agar objek yang dipersangkakan ditetapkan merupakan haknya dan bukan merupakan hak pihak lawannya.

\section{DAFTAR PUSTAKA}

Harahap, Yahya M. Permasalahan dan Penerapan Sita Jaminan (Conservatoir Beslag). Penerbit Pustaka, Bandung, 1990.

Harahap, Krisna. Hukum Acara Perdata Teori dan Praktek, PT Grafitri Budi Utami, Bandung, 1996.

Mertokusumo, Sudikno. Hukum Acara Perdata Indonesia, Liberty, Yogyakarta, 1998.

Muhamad, Abdulkadir, Hukum Acara Perdata Indonesia, PT Citra Aditya Bakti, Bandung, 1996.

Prinst, Darwan, Strategi Menyusun dan Menangani Gugatan Perdata, PT Citra Aditya Bakti, Bandung, 1996.

Prodjodikoro, Wirjono R. Hukum Acara Perdata di Indonesia, Sumur Bandung, Bandung, 1982.

Samudra, Teguh, Hukum Pembuktian dalam Acara Perdata, Alumni, Bandung, 1992.

Soepomo, Hukum Acara Perdata Pengadilan Negeri, Pradnya Paramita, Jakarta, 1993.

Sutantio, Retnowulan dan Iskandar Oeripkartawinata, Hukum Acara 
Perdata Dalam Teori dan Praktek, Mandar Maju, Bandung, 1997.

Subekti, R. Hukum Pembuktian, PT Pradnya Paramita, Jakarta, 1983. Hukum Acara Perdata, Bina Cipta, Bandung, 1998.

Subekti, R. dan R. Tjitrosudibio, Kitab Undang-undang Hukum Perdata, Pradnya Paramita, Jakarta. 2000.

Tresna, Komentar HIR, Pradnya Paramita, Jakarta, 1993.

\section{Sumber Perundang-undangan}

Undang-undang Republik Indonesia Nomor 48 Tahun 2009 Tentang Kekuasaan Kehakiman.

Undang-undang Republik Indonesia Nomor 4 Tahun 1998 Tentang Penetapan Peraturan Pemerintah Pengganti Undang-undang Nomor 1 Tahun 1998 tentang Perubahan Atas Undang-undang Kepailitan Menjadi Undangundang. 